\title{
Puromycin-sensitive aminopeptidase is the major peptidase responsible for digesting polyglutamine sequences released by proteasomes during protein degradation
}

\author{
N Bhutani ${ }^{1}$, P Venkatraman ${ }^{2}$ and \\ AL Goldberg* \\ Department of Cell Biology, Harvard Medical School, Boston, MA, USA
}

Long stretches of glutamine (Q) residues are found in many cellular proteins. Expansion of these polyglutamine (polyQ) sequences is the underlying cause of several neurodegenerative diseases (e.g. Huntington's disease). Eukaryotic proteasomes have been found to digest polyQ sequences in proteins very slowly, or not at all, and to release such potentially toxic sequences for degradation by other peptidases. To identify these key peptidases, we investigated the degradation in cell extracts of model Q-rich fluorescent substrates and peptides containing 10-30 Q's. Their degradation at neutral $\mathrm{pH}$ was due to a single aminopeptidase, the puromycin-sensitive aminopeptidase (PSA, cytosol alanyl aminopeptidase). No other known cytosolic aminopeptidase or endopeptidase was found to digest these polyQ peptides. Although tripeptidyl peptidase II (TPPII) exhibited limited activity, studies with specific inhibitors, pure enzymes and extracts of cells treated with siRNA for TPPII or PSA showed PSA to be the rate-limiting activity against polyQ peptides up to 30 residues long. (PSA digests such $Q$ sequences, shorter ones and typical (non-repeating) peptides at similar rates.) Thus, PSA, which is induced in neurons expressing mutant huntingtin, appears critical in preventing the accumulation of polyQ peptides in normal cells, and its activity may influence susceptibility to polyQ diseases. The EMBO Journal (2007) 26, 1385-1396. doi:10.1038/ sj.emboj.7601592; Published online 22 February 2007 Subject Categories: proteins; molecular biology of disease Keywords: cytosol alanyl aminopeptidase; glutamine expansion diseases; oligopeptidase; polyQ proteins; proteasome

\section{Introduction}

Polyglutamine (polyQ) diseases like Huntington's disease (HD) and spinocerebral ataxia (SCA 1-7) are a set of inherited neurodegenerative disorders caused by an expansion of the

*Corresponding author. Department of Cell Biology, Harvard Medical School, 240 Longwood Ave, Boston, MA 02115, USA.

Tel.: + 1617432 1855; Fax: + 1617232 0173;

E-mail: Alfred_Goldberg@hms.harvard.edu

${ }^{1}$ Present address: Department of Microbiology and Immunology,

Stanford University School of Medicine, 269 Campus Drive, Stanford, CA 94305, USA

${ }^{2}$ Present address: Cancer Research Institute (ACTREC), Mumbai, India

Received: 26 July 2006; accepted: 3 January 2007; published online: 22 February 2007
polyQ repeats in specific proteins. Normally, these proteins have sequences containing 6-35 Q repeats, but the mutated proteins contain sequences of 35-300 Q repeats (Zoghbi and Orr, 2000). Interestingly, the age of onset of disease symptoms is inversely correlated with the repeat length of the polyQ. The onset of the HD symptoms occurs typically at about 40 years when huntingtin has an expansion of 36-50 Q's, whereas a repeat length of 121 Q's results in the disease symptoms appearing in early childhood (Zoghbi and Orr, 2000). The pathological hallmark of these diseases is the presence of cytosolic and nuclear inclusions in specific regions of the brain (Davies et al, 1997). In HD, these inclusions include the full-length mutant huntingtin protein, $\mathrm{N}$-terminal fragments of these proteins containing the polyQ repeat, polyQ fragments from the wild-type huntingtin (Dyer and McMurray, 2001), as well as other cellular proteins bearing polyQ repeats (e.g. CREB and TATA box binding proteins) (Kazantsev et al, 1999; Steffan et al, 2000). These inclusions also contain ubiquitinated proteins and components of the ubiquitin-proteasome pathway (Davies et al, 1997; Waelter et al, 2001). Using specific proteasome inhibitors, it has been demonstrated in cultured cells as well as in animal models of HD that the normal as well as the expanded polyQ mutant proteins can be degraded by the ubiquitinproteasome pathway (Bence et al, 2001; Chai et al, 2001; Jana et al, 2001; Verhoef et al, 2002; Holmberg et al, 2004). However, recent studies have demonstrated a key role for the autophagic-lysosomal pathway in clearing the aggregates of the expanded polyQ mutant proteins (Ravikumar et al, $2002,2004)$. These studies suggest that although the proteasomal pathway can efficiently digest the normal polyQ-containing proteins, it fails to clear the aggregated expanded polyQ proteins that are instead cleared by the autophagiclysosomal pathway. Loss of bulk autophagy in the central nervous system has also been shown recently to lead to accumulation of protein aggregates and neurodegeneration in mice (Hara et al, 2006; Komatsu et al, 2006).

In eukaryotes, ubiquitinated proteins are hydrolyzed by the $26 \mathrm{~S}$ proteasome, an ATP-hydrolyzing complex that deubiquitinates, unfolds and translocates the substrate into the $20 \mathrm{~S}$ catalytic chamber where proteolysis takes place (Goldberg, 2003). The 20S proteasomes digest proteins to peptides that are 2-24 residues long, two-thirds of which are shorter than nine residues (Kisselev et al, 1999). The peptides released by proteasomes are initially digested by cellular endopeptidases, especially thimet oligopeptidase (TOP), and the resulting peptides are then hydrolyzed to amino acids by aminopeptidases (Saric et al, 2004). Although the majority of peptides released by the proteasome are digested completely, a small fraction of these peptides are taken up into the endoplasmic reticulum and function as the antigenic peptides 
that are presented on class I MHC molecules on the cell surface. This mechanism enables the immune system to screen for virally infected or cancer cells (Rock et al, 2004).

Recent studies in our lab demonstrated that the three types of active sites in eukaryotic proteasomes can cleave only very poorly (if at all) within polyQ sequences, even the short ones (10-20 Q's) found normally in a number of cell proteins (Venkatraman et al, 2004). These experiments used 20S core proteasomes with an open-gate so as to bypass the initial requirement for ubiquitination. While digesting a myoglobin fusion protein having a $\mathrm{Q}_{35}$ insertion, these proteasomes released the polyQ sequence intact (Venkatraman et al, 2004). As polyQ sequences do not accumulate in cells normally, they must be digested by other peptidases after being released by the proteasomes. The initial steps in the hydrolysis of most proteasomal products longer than 4-6 residues appear to be catalyzed by two major endopeptidases, tripeptidyl peptidase (TPPII) (Reits et al, 2004) and especially TOP (Saric et al, 2001; York et al, 2003). TPPII is an unusually large (5-9 MDa) proteolytic complex (Geier et al, 1999) that cleaves tripeptidases from the $\mathrm{N}$ terminus of peptides, but it may also have some endopeptidase activity. Although it had been proposed to have an important role in generating antigenic peptides from longer precursors (Seifert et al, 2003; Reits et al, 2004), TPPII is critical in vivo for trimming only those peptides that are greater than 15 residues, which comprise only a small fraction of the proteasomal product (York et al, 2006). By contrast, TOP has been shown to be responsible for degrading peptides ranging from 9 to 15 residues (about $25 \%$ of proteasome products) (Saric et al, 2001, 2004). Unlike TPPII, TOP has been observed to limit antigen presentation in vivo by destroying many antigenic peptides (York et al, 2003, 2006). Although several other cytosolic endopeptidases, specifically prolyl oligopeptidase (POP) (Fulop et al, 1998), insulin-degrading enzyme (IDE) (Farris et al, 2003), angiotensin-converting enzyme (ACE) (Hu et al, 2001) and neurolysin (Oliveira et al, 2001), have been characterized, they have not been shown to play key roles in the general breakdown of proteasomal products.

The final steps in hydrolysis of intracellular peptides to amino acids are carried out by aminopeptidases. Experiments in rats and cultured cells using the general aminopeptidase inhibitor, bestatin, showed an accumulation of di- and tripeptides, suggesting that aminopeptidases digest 2-3-residue peptides into amino acids (Botbol and Scornik, 1983). However, using N-terminal blocking of peptides injected in cells, it has been suggested that these aminopeptidases may be involved in digesting longer peptides as well (Reits et al, 2003). The major cytosolic aminopeptidases, bleomycin hydrolase (BH) (Stoltze et al, 2000), leucine aminopeptidase (LAP) (Beninga et al, 1998) and puromycin-sensitive aminopeptidase (PSA) also called 'cytosol alanyl aminopeptidase' (Constam et al, 1995; Stoltze et al, 2000), generally seem to show overlapping substrate specificities, and therefore appear to be largely redundant in the degradation of most proteasomal products, as also suggested by recent knockout studies (York, Rock et al, personal communication).

The present studies were undertaken to identify the key peptidases that digest the polyQ sequences released from the proteasomes, in order to understand the post-proteasomal steps by which the polyQ sequences in proteins are degraded to prevent the accumulation of these insoluble and potentially toxic peptides. Identification of these peptidases will help to understand why the proteasomal pathway, including the peptidases acting after the proteasome, fails to clear the proteins having expanded polyQ repeats although it can efficiently clear the proteins having normal polyQ repeats. The present biochemical studies have uncovered a unique capacity of PSA to digest polyQ sequences (and also long peptides), which imply an important role in protection against polyQ and possibly other protein folding diseases, as also suggested by recent transcriptional studies (Kita et al, 2002; Karsten et al, 2006).

\section{Results}

\section{Polyglutamine sequences are digested slowly by cell extracts}

Because purified eukaryotic proteasomes cleave polyQ sequences in proteins very slowly, if at all, and release polyQ fragments (Venkatraman et al, 2004), we tested if mammalian cells contain peptidase activities that can digest polyQ peptides released by the proteasomes. To screen for such enzymes, we initially used the peptide substrate $\mathrm{Q}_{20}$ RRGRR, which has free $\mathrm{N}$ - and C-terminal flanking basic residues to keep it soluble (this substrate preparation also contains some minor amount of $\mathrm{Q}_{19}$ RRGRR as an unavoidable contaminant; Venkatraman et al, 2004). Using MALDITOF MS, we observed that soluble HeLa extracts digested $\mathrm{Q}_{20}$ RRGRR sequentially to $\mathrm{Q}_{19}$ RRGRR, $\mathrm{Q}_{18}$ RRGRR, $\mathrm{Q}_{17}$ RRGRR, $\mathrm{Q}_{16}$ RRGRR and shorter fragments (Figure 1). The rate of digestion of $\mathrm{Q}_{20} \mathrm{RRGRR}$ by the HeLa extracts could be assayed by quantitatively measuring the $\mathrm{N}$ termini of the new peptide products generated. To compare the rate with a typical, non-repeat 25-residue peptide, we used a collection of peptides with the general sequence RY $(\mathrm{X})_{19} \mathrm{NKTL}$, where ' $\mathrm{X}$ ' is an equimolar mixture of $\mathrm{A}, \mathrm{D}, \mathrm{E}, \mathrm{F}, \mathrm{G}, \mathrm{H}, \mathrm{I}, \mathrm{K}, \mathrm{L}$, $\mathrm{M}, \mathrm{P}, \mathrm{Q}, \mathrm{R}, \mathrm{S}, \mathrm{T}$ or $\mathrm{V}$. The rate of digestion of $\mathrm{Q}_{20} \mathrm{RRGRR}$ (1.5 pmol peptide cleavages $/ \mathrm{h} / \mu \mathrm{g}$ ) was 15 -fold lower than that of the 25 -residue peptide library $(22 \mathrm{pmol} / \mathrm{h} / \mu \mathrm{g})$. Thus, the digestion of the polyQ peptide occurs, but is very slow as compared to the rapid clearance of more typical peptides.

Purified eukaryotic proteasomes can cleave bonds in $\mathrm{Q}_{20} \mathrm{RRGRR}$ only in the $\mathrm{C}$-terminal basic flanking residues to generate $\mathrm{Q}_{20} \mathrm{RRG}$ (similarly, the proteasomes generate $\mathrm{Q}_{19} \mathrm{RRG}$ from the $\mathrm{Q}_{19} \mathrm{RRGRR}$ peptide that contaminates the substrate) (Venkatraman et al, 2004). The observed digestion pattern suggested that the cell extracts, unlike the proteasomes, do not make any cuts in the flanking C-terminal RRGRR sequence. The digestion products in the HeLa extract did not change upon incubation in the presence of specific proteasome inhibitors, epoxomicin and PS 341, even though the HeLa extract had functionally active proteasomes as they digested rapidly the standard fluorogenic substrate (SucLLVY-amc) as well as protein substrates (casein) (data not shown). We therefore decided to fractionate these extracts in order to identify the peptidases that digest the polyQ peptide. These observations also confirm our earlier findings that mammalian cell extracts lack carboxypeptidase activities (Beninga et al, 1998; Saric et al, 2004). 


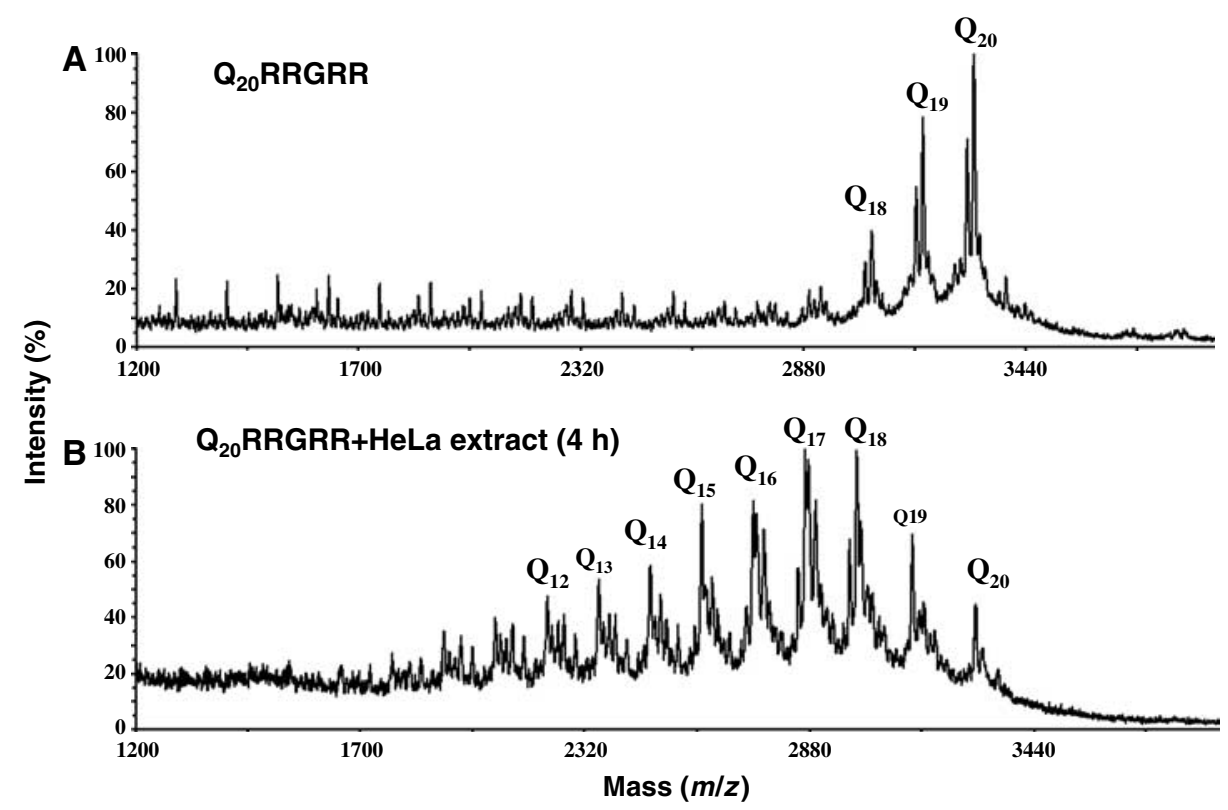

Figure 1 PolyQ sequences are digested in HeLa cell extracts by an exopeptidase activity. $\mathrm{Q}_{20}$ RRGRR (15 $\mu \mathrm{M}$ ) (which contains some contaminating $\mathrm{Q}_{19} \mathrm{RRGRR}$ and traces of $\mathrm{Q}_{18} \mathrm{RRGRR}$ ) was incubated alone (A) and with $10 \mu \mathrm{g}$ of freshly prepared HeLa extracts in $50 \mu \mathrm{l}$ (B) for $4 \mathrm{~h}$ at $37^{\circ} \mathrm{C}$ and the reaction mixtures were analyzed by MALDI-TOF. Sequential loss of Q residues indicates aminopeptidase activity.

\section{Identification of cellular peptidases active against polyQ sequences}

To assay the polyQ-degrading activity in different fractions, we designed an internally quenched fluorescent substrate where the fluorescent (EDANS (5-[(2-aminoethyl) amino]naphthalene-1-sulfonic acid)) and fluorescence-quenching group (DABSYL (4'-dimethylaminoazobenzene-4'-sulfonyl)) were separated by 9 Q's $\left(\mathrm{KKE}^{(\text {EDANS })} \mathrm{Q}_{9} \mathrm{~K}^{(\text {DABSYL })} \mathrm{K}\right)$. Thus, a single endopeptidyl cut within this glutamine stretch would lead to an increase in the fluorescence signal. We also used the fluorescent substrate Q-amc to monitor any aminopeptidase activity capable of removing $\mathrm{Q}$ residues. However, we also found that repeated exopeptidase cleavages could release the fluorescent EDANS from the quencher (see below).

The cytosolic HeLa homogenates were centrifuged at $100000 \mathrm{~g}$ for $6 \mathrm{~h}$ to remove nearly all the proteasomes and the extremely large cytosolic peptidase, TPPII. Therefore, we also tested a purified preparation of TPPII separately for its ability to cleave polyQ sequences (see below). Removal of these high-molecular-weight enzymes had little or no effect on the hydrolysis of the quenched $\mathrm{Q}_{9}$ substrate or Q-amc. Upon fractionation of the high-speed supernatants on a DEAE column, one large peak of activity was found against the quenched $\mathrm{Q}_{9}$ substrate $(10 \mu \mathrm{M})$ (Figure $\left.2 \mathrm{~A}\right)$. To our surprise, it appeared to correspond to an aminopeptidase, as it was also the only peak able to hydrolyze Q-amc $(100 \mu \mathrm{M})$ (Figure $2 \mathrm{~A}$ ). The activity against both these substrates coincided exactly, but the peaks were broad. We therefore fractionated it further on a Resource ${ }^{\mathrm{TM}} \mathrm{RPC}$ hydrophobic column. The eluted fractions from this column (Figure 2B) showed two sharp activity peaks with overlapping activities against both the substrates. When the ability of the two peaks to hydrolyze the $\mathrm{Q}_{9}$ fluorescent peptide was assayed using MALDI-TOF MS, only peak 2 generated peptide products (not shown). By contrast, the less active peak 1 only appeared to increase the fluorescence of the peptide without cleaving its peptide bonds. We therefore focused on peak 2 .

The fractions corresponding to peak 2 were pooled, concentrated, desalted and further fractionated on a CHT hydroxyapatite column. There was no activity in the flow-through fractions. Upon batch-elution in steps of $0.1 \mathrm{M}$ phosphate, only the $0.2 \mathrm{M}$ phosphate peak showed activity against both the substrates. The $0.2 \mathrm{M}$ fractions were desalted, concentrated and analyzed by native PAGE. An activity overlay assay of the gel using either $\mathrm{Q}$-amc or the quenched $\mathrm{Q}_{9}$ substrate showed a single, distinct band (Figure 2C), which was excised, eluted and subjected to SDS-PAGE. Two bands corresponding to 98 and $62 \mathrm{kDa}$, respectively, were visible on the gel by silver staining (Figure 2D). The excised native gel band was also subjected to liquid chromatography coupled with mass spectrometry (LC/MS/MS), and 41 peptides corresponding to different parts of the human PSA sequence, 40 peptides corresponding to the human alanyl t-RNA synthetase and 24 peptides corresponding to different parts of the human annexin sequence were identified. The molecular weights of PSA, alanyl-tRNA synthetase and annexin are 98, 107 and $62 \mathrm{kDa}$ respectively. Various other proteins were identified with a much lower number of peptide matches. PSA was identified as the only active peptidase present, as the activity against both these substrates was completely inhibited by puromycin, a specific inhibitor of PSA (Hersh, 1981), as well as by the general aminopeptidase inhibitor bestatin (Umezawa et al, 1976) (data not shown). Also pure PSA rapidly digested each substrate (data not shown).

\section{Purified PSA can digest $C K K Q_{20} K K$ as well as $K K Q_{30} K K$ peptide}

To test the ability of PSA to digest larger Q peptides, $15 \mu \mathrm{M}$ each of $\mathrm{CKKQ}_{20} \mathrm{KK}$ and $\mathrm{KKQ}_{30} \mathrm{KK}$ was incubated with $0.3 \mu \mathrm{g} /$ $\mu \mathrm{l}$ of PSA (pooled, concentrated fractions from CHT column) 


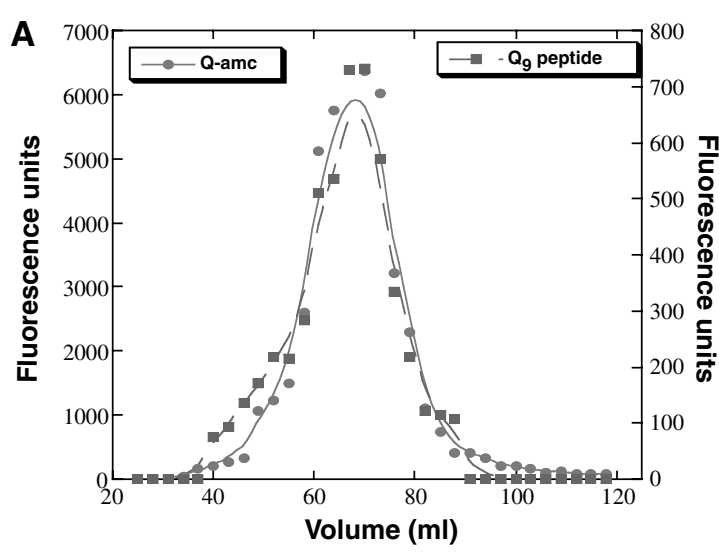

C Extract Q-active pool
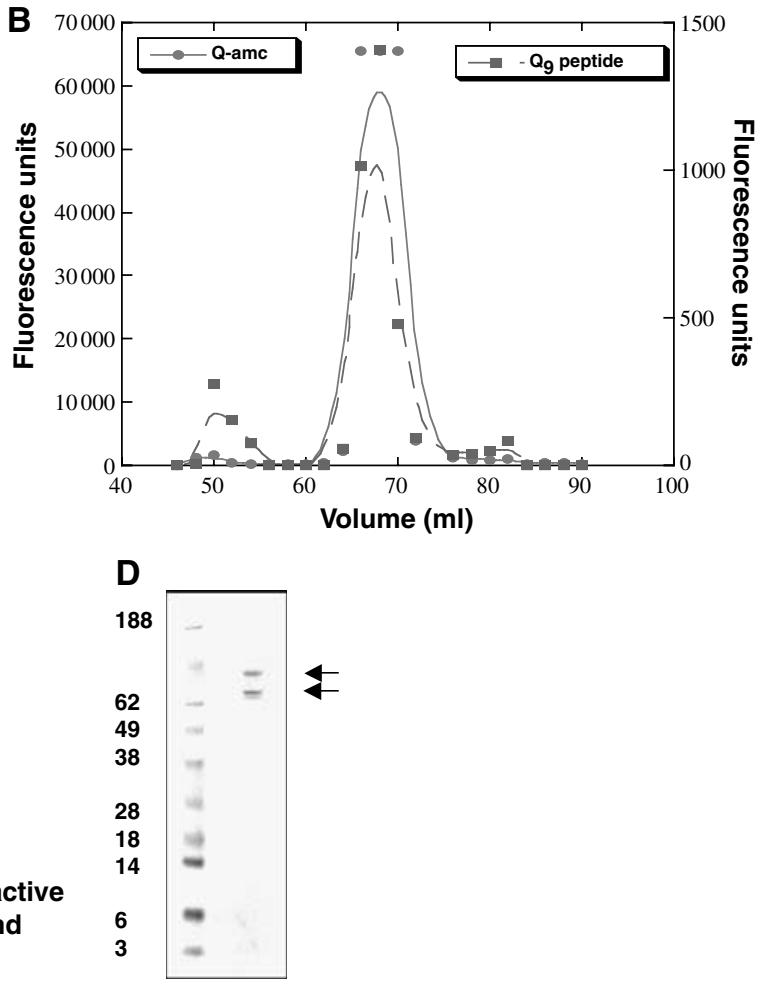

Figure 2 Identification of PSA as the enzyme active against the aminopeptidase substrate Q-amc and the quenched fluorescent substrate $\mathrm{KKE}^{\text {(EDANS) }} \mathrm{Q}_{9} \mathrm{~K}^{\text {(DABSYL) }} \mathrm{K}$ designed to detect endopeptidase(s) cleaving within the $\mathrm{Q}_{9}$ sequence, but also able to detect repeated aminopeptidase cleavages that sequentially remove KKE ${ }^{\text {(EDANS) }}$ residues. (A) A $50 \mathrm{mg}$ portion of $65000 \mathrm{~g}$ HeLa extract was fractionated on a DEAE column as described in Materials and methods. Five-microliter aliquots were analyzed for their ability to hydrolyze $100 \mu \mathrm{M}$ Q-amc and $10 \mu \mathrm{M}$ $\mathrm{KKE}^{(\mathrm{EDANS})} \mathrm{Q}_{9} \mathrm{~K}^{(\mathrm{DABSYL})} \mathrm{K}$. A single, overlapping activity peak was observed against both the substrates. The corresponding fractions were pooled, concentrated and further fractionated on a Resource Q column. Five-microliter aliquots were analyzed for their ability to hydrolyze $100 \mu \mathrm{M}$ Q-amc and $10 \mu \mathrm{M} \mathrm{KKE}{ }^{(\text {EDANS })} \mathrm{Q}_{9} \mathrm{~K}^{(\mathrm{DABSYL})} \mathrm{K}$. (B) The activity profile against both the substrates showed two sharp peaks. Fractions from the second peak were pooled and the proteins separated on a CHT hydroxyapatite column. (C) Native gel activity overlay using the fluorogenic substrate Q-amc. Active fractions from the CHT hydroxyapatite column were pooled, concentrated and run on a native PAGE labeled as the Q-active pool along with $65000 \mathrm{~g}$ HeLa extract. The corresponding Q-amc active band was excised and run on an SDS-PAGE. (D) Two bands corresponding to 98 and $62 \mathrm{kDa}$ were visible. Using mass spectrometry, the $98 \mathrm{kDa}$ band was identified as the human PSA and the $62 \mathrm{kDa}$ band was identified as annexin.

for $2 \mathrm{~h}$ and the products generated were analyzed using MALDI-TOF MS. PSA could digest both peptides sequentially. In a typical aminopeptidase fashion, PSA removed one Q residue at a time from both peptide substrates (Figure 3 ). Digestion of both peptides was completely inhibited by puromycin, a specific inhibitor of PSA, as well as the general aminopeptidase inhibitor bestatin (data not shown). Also, recombinant PSA (kindly provided by L Hersh) was found to digest $\mathrm{CKKQ}_{20} \mathrm{KK}$ and $\mathrm{KKQ}_{30} \mathrm{KK}$ by a similar aminopeptidase mechanism (data not shown). The rate of digestion of $\mathrm{CKKQ}_{20} \mathrm{KK}$ by purified PSA $(0.3 \mathrm{nmol} / \mathrm{h} / \mu \mathrm{g})$ was similar to the rate of digestion of a typical (non-repetitive) 20-residue peptide lacking Q residues, ANATKVSKNLEKNVSKNLEY, in contrast to the crude cell extracts, which degraded the peptide lacking $\mathrm{Q}$ residues much faster. This result is consistent with the presence in the cells of multiple endopeptidases and aminopeptidases active against other peptide sequences, but only one, PSA, was capable of rapidly digesting polyQ sequences.

\section{Pure TPPII shows little activity against $\boldsymbol{Q}_{20} \boldsymbol{R} R \mathbf{R} R$}

The HeLa extracts that we analyzed were centrifuged at high speeds to remove proteasomes as well as TPPII. Upon resus- pension, there was no activity against $\mathrm{Q}_{20} \mathrm{RRGRR}$; however, TPPII rapidly loses activity under these conditions (unpublished observations). We therefore tested whether purified TPPII can degrade polyQ sequences. Using MALDI-TOF MS, we observed that TPPII could release three residues from $\mathrm{Q}_{20}$ RRGRR to form $\mathrm{Q}_{17} \mathrm{RRGRR}$ and then $\mathrm{Q}_{14} \mathrm{RRGRR}$ (Figure 4). However, the rate of digestion of $\mathrm{Q}_{20} \mathrm{RRGRR}$ by TPPII $(0.008 \mathrm{nmol} / \mathrm{h} / \mu \mathrm{g})$ was 50 -fold lower than the rate of digestion of the non-repeat 21-residue peptide insulin chain $\mathrm{A}$ $(0.4 \mathrm{nmol} / \mathrm{h} / \mu \mathrm{g})$, suggesting that $\mathrm{Q}_{20} \mathrm{RRGRR}$ is quite resistant to TPPII as compared to a typical peptide lacking $\mathrm{Q}$ repeats. Furthermore, no digestion was observed when TPPII was tested against a longer $\mathrm{Q}$ peptide, $\mathrm{KKQ}_{30} \mathrm{KK}$ (data not shown). These experiments and the sensitivity of crude extracts to inhibitors of PSA indicate that TPPII does not contribute significantly to the digestion of polyQ sequences released by proteasomes.

\section{Lack of activity of other cytosolic peptidases}

It was surprising that none of the other known cytosolic endopeptidases were identified in the screen using the $\mathrm{Q}_{9}$ fluorescent peptide or Q-amc as substrates. Therefore, we tested the activity of purified preparations of the major 

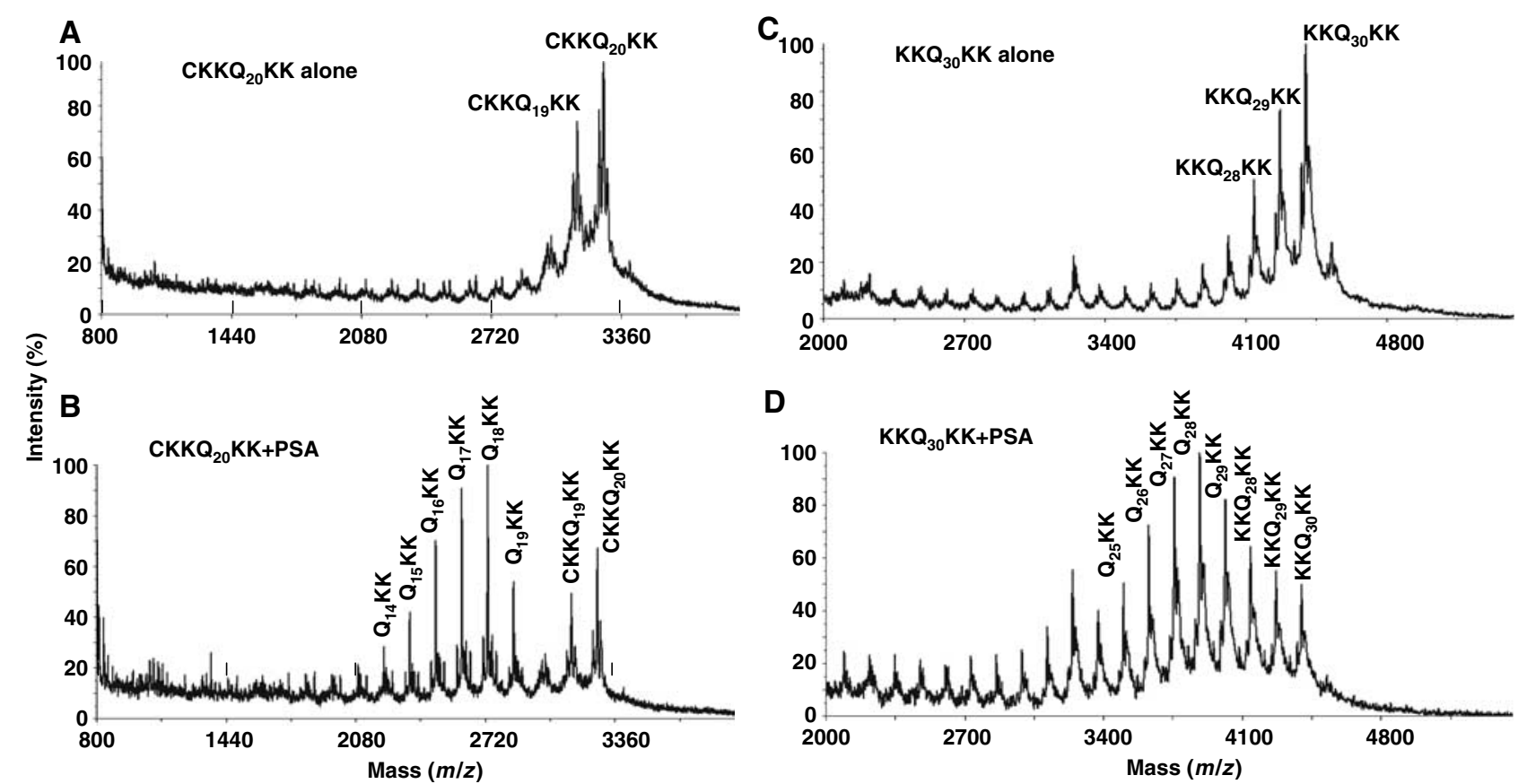

Figure 3 PSA can digest $\mathrm{CKKQ}_{20} \mathrm{KK}$ as well as $\mathrm{KKQ}_{30} \mathrm{KK}$. $\mathrm{CKKQ}_{20} \mathrm{KK}(15 \mu \mathrm{M})(\mathbf{A})$ and $\mathrm{KKQ}_{30} \mathrm{KK}(15 \mu \mathrm{M})(\mathbf{B})$ were incubated with $6.8 \mu \mathrm{g}$ of partially purified PSA in $20 \mu \mathrm{l}$ reactions for $2 \mathrm{~h}$ at $37^{\circ} \mathrm{C}$ and the reaction mixtures were analyzed by MALDI-TOF. PSA digested both substrates to shorter products by sequential aminopeptidase action (C) and (D).

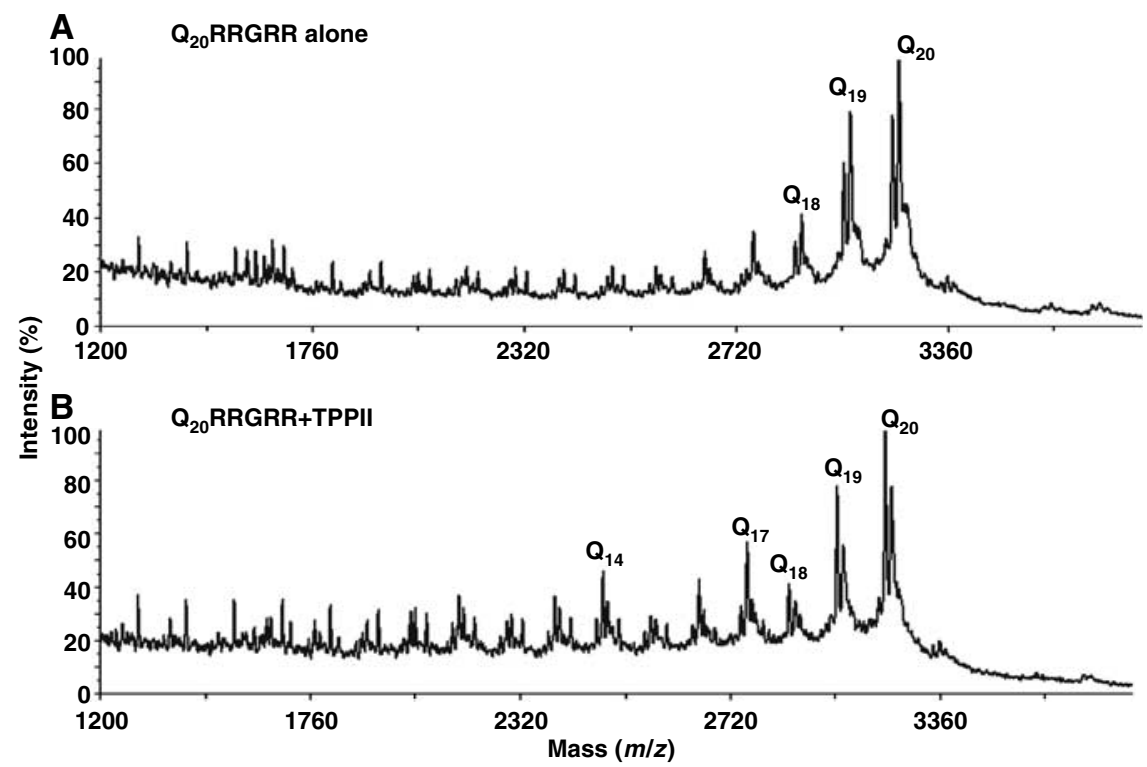

Figure 4 Pure TPPII shows limited tripeptidyl aminopeptidase activity against $\mathrm{Q}_{20}$ RRGRR. $\mathrm{Q}_{20} \mathrm{RRGRR}(15 \mu \mathrm{M})$ was incubated alone (A) and with $6 \mu \mathrm{g}$ of purified TPPII in $20 \mu \mathrm{l}$ reactions (B) for $4 \mathrm{~h}$ at $37^{\circ} \mathrm{C}$ and the reaction mixtures were analyzed by MALDI-TOF. The production of $\mathrm{Q}_{17} \mathrm{RRGRR}$ indicates a tripeptidyl peptidase activity.

intracellular endopeptidases against the $\mathrm{Q}_{10}$ and $\mathrm{Q}_{20}$ peptides. Neither recombinant POP nor a partially purified preparation of human TOP, which plays a major role in degrading proteasomal products 9-16 residues long (York et al, 2003; Saric et al, 2004), could digest $\mathrm{Q}_{20} \mathrm{RRGRR}$ or $\mathrm{KKQ}_{20} \mathrm{KK}$ (data not shown). We also tested commercially available recombinant ACE and IDE, both of which have been implicated in the degradation of the Alzheimer's $\beta$-amyloid precursor protein (Hu et al, 2001; Farris et al, 2003)-neither showed any activity against the $\mathrm{Q}_{20}$ peptides, as shown by measuring new amino groups generated or MALDI-TOF MS (data not shown). Finally, the two major cytosolic aminopeptidases, purified, recombinant LAP and $\mathrm{BH}$, were also found to be inactive against $\mathrm{Q}_{20} \mathrm{RRGRR}, \mathrm{KKQ}_{20} \mathrm{KK}$ as well as $\mathrm{KKQ}_{30} \mathrm{KK}$ (data not shown), in sharp contrast to findings with PSA.

\section{Studies to clarify the importance of PSA and TPPII in degrading polyQ peptides}

To study the metabolism of polyQ peptides in extracts containing functional proteasomes, TPPII and particulate 
enzymes, we prepared fresh HeLa lysates using only lowspeed centrifugation (10000g for $15 \mathrm{~min})$. TPPII was observed to be active in these extracts, using the standard fluorogenic substrate AAF-amc. The activity of these extracts was then tested against several polyQ peptides, Q-amc and $\mathrm{KKE}^{(\text {EDANS) }} \mathrm{Q}_{9} \mathrm{~K}^{(\mathrm{DABSYL})} \mathrm{K}$ (Table I), in the presence or absence of butabindide, the specific TPPII inhibitor (Rose et al, 1996), as well as puromycin, the specific inhibitor for PSA, bestatin, an inhibitor of most aminopeptidases (including PSA), MG132, the proteasome inhibitor, and E64, the cysteine protease inhibitor. In the presence of puromycin, the extract activity was inhibited by 86 or $94 \%$ (with Q-amc), and in the presence of bestatin, there was an inhibition of 69 or $33 \%$ (with Q-amc). Surprisingly, there was no effect of the TPPII

Table I Digestion of fluorogenic polyQ substrates tested in the presence of specific protease inhibitors

\begin{tabular}{lc}
\hline HeLa extract activity against KKE ${ }^{(\mathrm{EDANS})}$ QQQ QQQ QQQ K & \\
\% Inhibition & 0 \\
No inhibitor & 0 \\
Butabindide $(4 \mathrm{nM})$ & 69 \\
Bestatin $(100 \mu \mathrm{M})$ & 86 \\
Puromycin $(100 \mu \mathrm{M})$ & 0 \\
MG132 $(100 \mu \mathrm{M})$ & 0 \\
E64 $(100 \mu \mathrm{M})$ & \\
& \\
HeLa extract activity against Q-amc & \\
\% Inhibition & 0 \\
No inhibitor & 0 \\
Butabindide $(4 \mathrm{nM})$ & 33 \\
Bestatin $(100 \mu \mathrm{M})$ & 94 \\
Puromycin $(100 \mu \mathrm{M})$ & 0 \\
MG132 $(100 \mu \mathrm{M})$ & 6 \\
E64 $(100 \mu \mathrm{M})$ & \\
\hline
\end{tabular}

inhibitor butabindide, even though TPPII was active in these extracts as shown using the specific substrate AAF-amc. Moreover, butabindide was able to completely inhibit its hydrolysis although not affecting the polyQ substrates. Therefore, the major, rate-limiting peptidase acting on the polyQ peptides in these extracts is PSA.

As observed using MALDI-TOF MS (Figure 5), $\mathrm{Q}_{20} \mathrm{RRGRR}$ is digested in these HeLa extracts by sequential aminopeptidase action. The addition of butabindide had no inhibitory effect, whereas the digestion was strongly inhibited by the presence of puromycin. These findings thus confirm the results obtained with the quenched $\mathrm{Q}_{9}$ peptide and $\mathrm{Q}$-amc. To further investigate the contributions of these two enzymes, we tried to eliminate their expression with siRNA. HeLa cells were treated with control siRNA directed against mouse TOP (5'-CCUCAACGAGGACACCACCdTdT- $3^{\prime}$ and $5^{\prime}$ GGUGGUGUCCUCGUUGAGGdTdT-3' corresponding to bases 673-691 of mouse TOP), siRNA specific for TPPII (5'-CAAC UCACUGGCCAAAUU dTdT-3' and 5'-AAUUUGGCCAGUGA GUUGC dTdT-3' corresponding to bases 1017-1035 of human TPPII) and siRNA specific for PSA (5'-GAGUCCUUGG CGCUACUC UdTdT- $3^{\prime}$ and 5'-AGAGUAGCGCCAAGGACUCdT dT-3' corresponding to bases 2405-2423 of human PSA). mRNA levels for both enzymes were drastically reduced 3 or 4 days after transfection (Supplementary Figure 1A and C), and there was a decrease in the specific enzymatic activity of TPPII by about $90 \%$ and of PSA by $80 \%$ (Supplementary Figure $1 \mathrm{~B}$ and $\mathrm{D}$ ). The extent of $\mathrm{Q}_{20}$ RRGRR digestion (Figure 6) was identical in the wild-type HeLa extract and the TPPII siRNA-treated HeLa extract, whereas there was hardly any digestion of $\mathrm{Q}_{20}$ RRGRR by the PSA siRNA-treated HeLa extracts. These experiments clearly established that

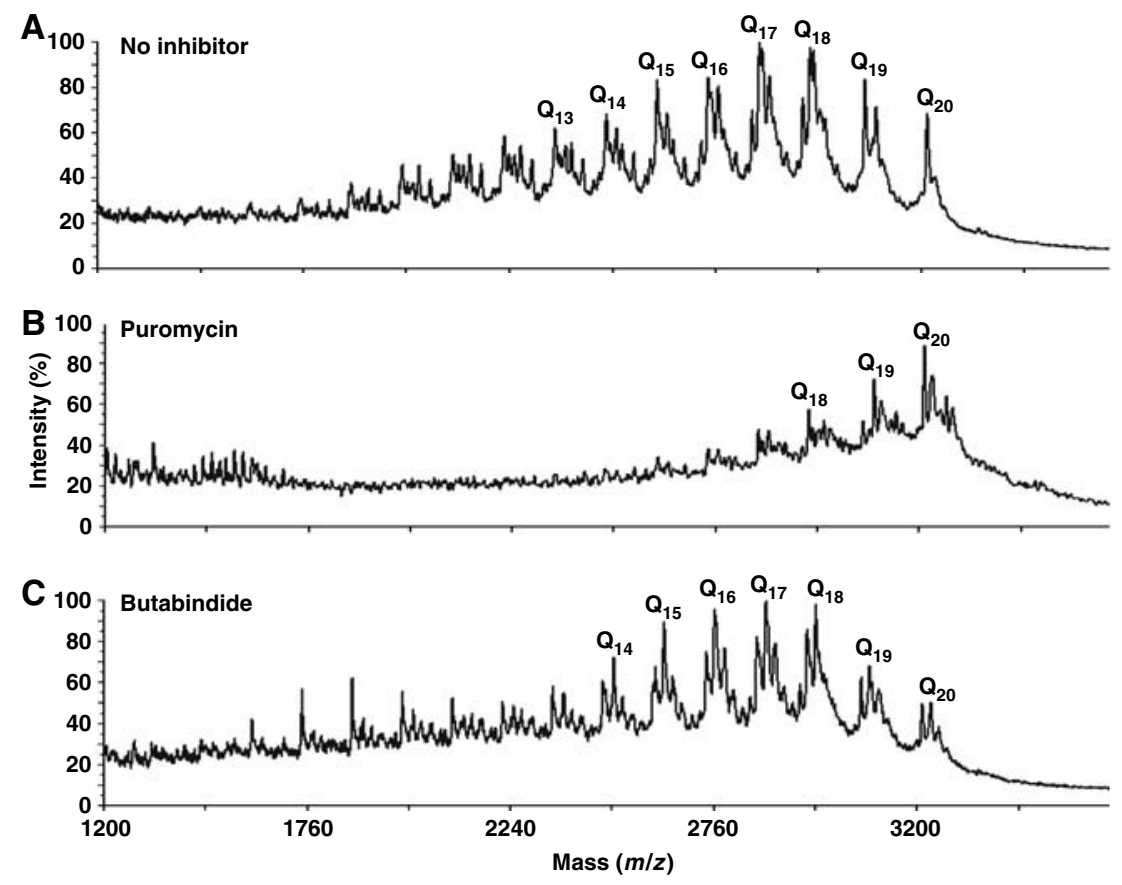

Figure 5 In extracts, PSA and not TPPII is mainly responsible for digesting Q peptides. Q $_{20}$ RRGRR $(15 \mu \mathrm{M})$ was incubated (A) with $10 \mu \mathrm{g}$ of cytosolic HeLa extracts in $10 \mu \mathrm{l}$, (B) in the presence of $100 \mu \mathrm{M}$ puromycin, a specific inhibitor of PSA, and (C) in the presence of $4 \mathrm{nM}$ butabindide, a specific inhibitor of TPPII, and, for $4 \mathrm{~h}$ at $37^{\circ} \mathrm{C}$, and the reaction mixtures were analyzed by MALDI-TOF. Before the reaction, the extracts were preincubated with the respective inhibitors for $20 \mathrm{~min}$ at room temperature. In the presence of puromycin, there was no digestion of $\mathrm{Q}_{20} \mathrm{RRGRR}$ at all (no change from time 0), whereas in the presence of butabindide, there was sequential digestion of $\mathrm{Q}_{20} \mathrm{RRGRR}$ as in the absence of any inhibitor. Also, no TPPII activity was detected even in the presence of puromycin. 

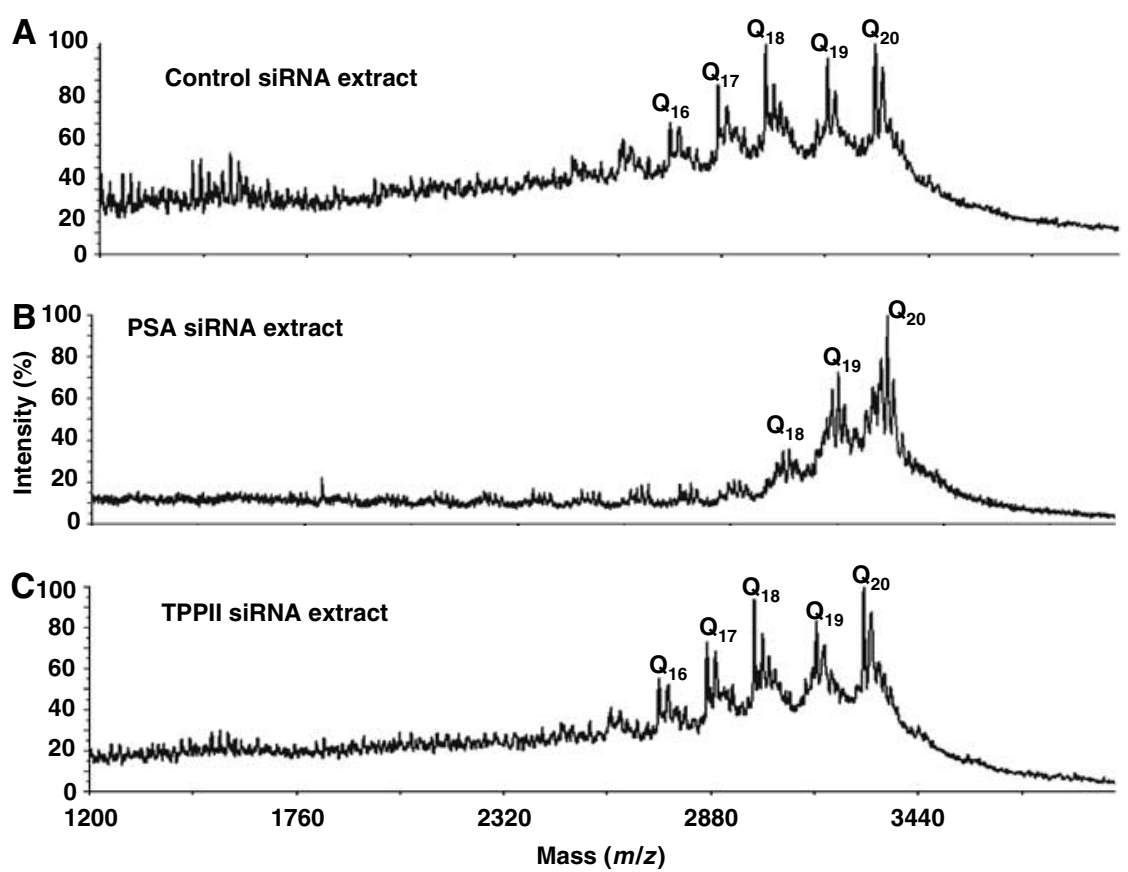

Figure 6 Elimination of PSA by siRNA prevents the digestion of $\mathrm{Q}_{20}$ RRGRR but reduction of TPPII by siRNA has no effect on the digestion $\mathrm{Q}_{20} \mathrm{RRGRR}(15 \mu \mathrm{M})$ was incubated in a $20 \mu \mathrm{l}$ reaction (A) with $10 \mu \mathrm{g}$ of cytosolic HeLa extracts transfected with control siRNA directed against mouse TOP, (B) with siRNA against human PSA and (C) with siRNA against human TPPII (exact oligonucleotide sequences are described in Results and Materials and methods) for $4 \mathrm{~h}$ at $37^{\circ} \mathrm{C}$ and the reaction mixtures were analyzed by MALDI-TOF. Digestion of $\mathrm{Q}_{20} \mathrm{RRGRR}$ was completely blocked (no change from time 0 ) in the presence of PSA siRNA-treated HeLa extracts, whereas the digestion of $\mathrm{Q}_{20}$ RRGRR in the presence of TPPII siRNA was indistinguishable from control. Also, no TPPII activity was detected even in the presence of reduced PSA expression.
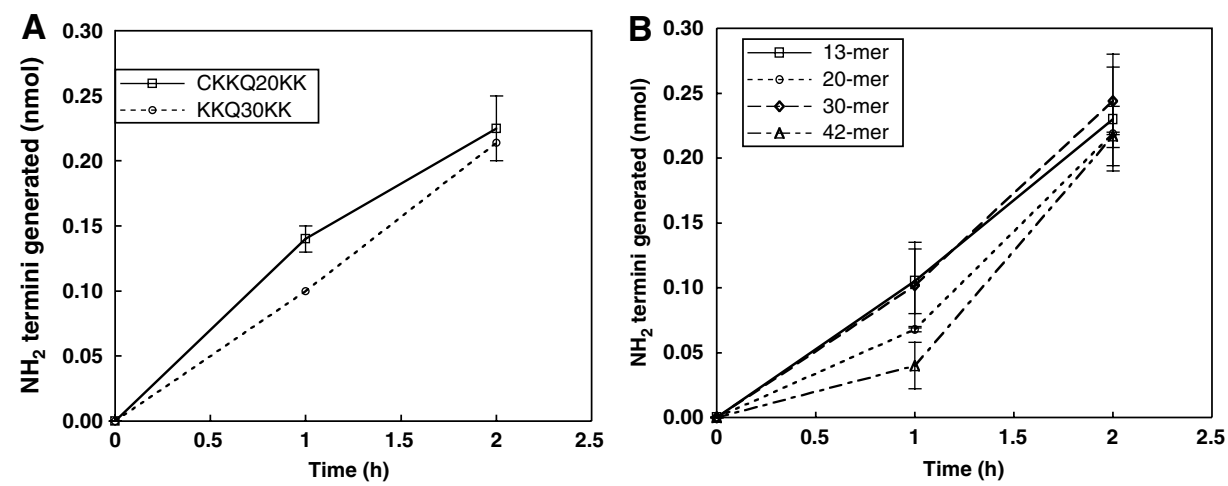

Figure 7 (A) PSA digests at similar rates $\mathrm{CKKQ}_{20} \mathrm{KK}$ and $\mathrm{KKQ}_{30} \mathrm{KK}$ as well as a set of non-repeat peptides (B) with 13, 20, 30 and 42 residues having identical N- and C-terminal residues. These N-terminal residues were ANATKVLEVSLEY (13), ANATKVSKNLE-KNVSKNLEY (20), ANATKKNSLEVSKNLELEKNVSVSKNLEY (30), ANATKKNLEVSVSLEKNKNSLEVSKNLELEKNVSVSKNLEY (42). Their degradation at comparable rates indicates an ability of PSA to attack quite long polypeptides. A $15 \mu \mathrm{M}$ portion of each peptide was incubated with $6.8 \mu \mathrm{g}$ of PSA in a $20 \mu \mathrm{l}$ reaction at $37^{\circ} \mathrm{C}$ and the number of new $\mathrm{N}$ termini generated was assayed, as described in Materials and methods. Error bars indicate standard errors calculated from three independent experiments.

PSA is the only protease that can cleave the polyQ sequences in the cytosol at $\mathrm{pH} 7$, and hence is probably responsible for the degradation of the polyQ peptides released from the proteasome.

\section{Influence of substrate length on susceptibility to PSA}

Generally, aminopeptidases (including PSA) preferentially digest short peptides 3-5 residues long, and most cannot act on substrates longer than oligopeptides (Chang et al, 2005). Therefore, we examined the ability of PSA to hydrolyze polyQ peptides of increasing repeat length. The Q-pep- tides studied were $\mathrm{CKKQ}_{20} \mathrm{KK}$ and $\mathrm{KKQ}_{30} \mathrm{KK}$, which correspond to the lengths of polyQ sequences in some normal proteins. Longer peptides, which would reflect the polyQ sequences present in the disease states, such as $\mathrm{KKQ}_{50} \mathrm{KK}$, could not be tested with PSA, as these peptides are extremely aggregation-prone and have very limited solubility (even with the terminal basic residues). (Also, longer polyQ peptides such as $\mathrm{KKQ}_{50} \mathrm{KK}$ are difficult to detect by MALDI-TOF.) PSA cleaved $\mathrm{CKKQ}_{20} \mathrm{KK}$ and $\mathrm{KKQ}_{30} \mathrm{KK}$ at very similar rates (Figure 7A). In order to compare, we also tested the ability of PSA to digest peptides of increasing lengths using a set of 


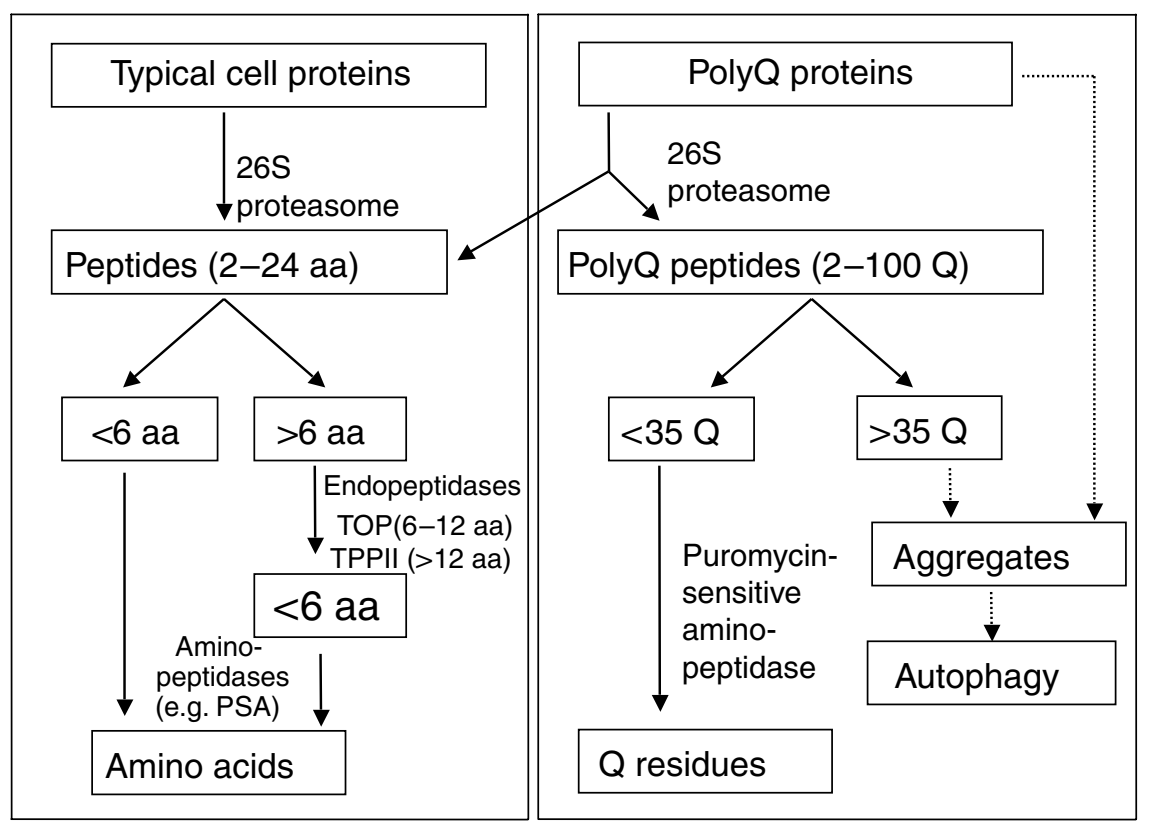

Figure 8 Summary of pathways for degradation of a typical non-repeat cell protein and of a polyQ protein, based on the present observation.

non-repeat peptides with $13,20,30$ and 42 residues having similar N-terminal residues: ANATKVLEVSLEY (13), ANA TKVSKNLEKNVSKNLEY (20), ANATKKNSLEVSK NLELEK NVSVSKNLEY (30) and ANATKKNLEVSVSLEKNKNSLEV SKNLELEKNVSVSKNLEY (42). Surprisingly, the rates of digestion of these 13-, 20-, 30- and 42-residue peptides were very similar and comparable to the rates of $\mathrm{Q}$ peptides with polyQ $\mathrm{N}$ termini (Figure 7). Thus, PSA, unlike any other cytosolic enzyme, can digest Q peptides as efficiently as nonrepeat peptides. This unusual capacity of an aminopeptidase to digest such long polypeptides can account for the recently discovered ability of PSA to degrade Tau in vivo and in neurons (Karsten et al, 2006), and further suggests a role in the elimination of normal-length $\mathrm{Q}$ sequences released by proteasomes and perhaps also the expanded polyQ sequences that may be generated in polyQ diseases.

\section{Discussion}

The present studies further clarify the pathway of degradation of polyQ-containing proteins under normal conditions and may have important implications for understanding the accumulation of polyQ proteins and fragments during disease states. Our earlier studies showed that the eukaryotic proteasomes while degrading polyQ proteins cannot digest the polyQ sequences and release these sequences intact (Venkatraman et al, 2004). As shown here, the only cytosolic peptidase capable of digesting these polyQ peptides is the PSA. By fractionation of cell extracts and using purified cytosolic peptidases, we found that PSA was the only peptidase active against a variety of $\mathrm{Q}$ peptides. The only other peptidase showing any activity against the Q peptides at $\mathrm{pH} 7$ was TPPII, a large (5-9 MDa) enzyme complex (Geier et al, 1999) having a unique spindle-shaped structure formed of two twisted strands (Rockel et al, 2002, 2005). Although the biological importance of its complex architecture remains unknown, it has been shown to play a minor role in the generation of antigenic peptides, particularly for the trimming of peptides greater than 15 residues (Seifert et al, 2003; Reits et al, 2004; York et al, 2006). Purified TPPII could cleave QQQ peptides from $\mathrm{Q}_{20} \mathrm{RRGRR}$ but the rate of digestion for $\mathrm{Q}_{20}$ RRGRR was 50-fold lower than the degradation of a control peptide lacking $\mathrm{Q}$ repeats. TPPII, unlike PSA, failed also to cleave the longer $\mathrm{KKQ}_{30} \mathrm{KK}$. Moreover, experiments with specific inhibitors as well as RNAi showed that PSA, and not TPPII, is mainly responsible for the digestion of $\mathrm{Q}$ peptides in cell extracts. Also, no other endopeptidase, including TOP, which hydrolyzes many longer proteasomal products (Saric et al, 2001; York et al, 2003), and no cytosolic aminopeptidases, including LAP and $\mathrm{BH}$, could digest these $\mathrm{Q}$ peptides, even though these enzymes contribute to the very rapid elimination of other proteasomal products.

PSA is a ubiquitous $100 \mathrm{kDa}, \mathrm{Zn}^{2+}$ metallopeptidase present in high concentrations in mammalian brain (especially cerebellum; Karsten et al, 2006) from which it was initially purified as an enkephalin-degrading aminopeptidase (Hersh et al, 1980). PSA exists primarily in soluble form in the cytosol and nucleus, but is also found in a membranebound form and associated with the microtubule-spindle apparatus during mitosis (Constam et al, 1995). PSA has been proposed to function in a number of processes including metabolism of neuropeptides (Hersh et al, 1980; Hersh and McKelvy, 1981), regulation of the cell cycle (Constam et al, 1995), processing of antigenic peptides for presentation on MHC Class I molecules (Stoltze et al, 2000) and hydrolysis of proteasomal products to amino acids (Botbol and Scornik, 1983; Saric et al, 2004). It has a broad specificity against various $\mathrm{N}$-terminal residues with some preference for basic and hydrophobic amino acids (Johnson and Hersh, 1990; Constam et al, 1995; Stoltze et al, 2000). Although the residues important for substrate binding have been defined (Thompson et al, 2003; Thompson and Hersh, 2003), they do not explain its unusual capacity to bind to Q peptides. Unlike proteasomes and most peptidases which bind these Q pep- 
tides very poorly, PSA digests even long polyQ sequences at rates similar to Q-free sequences.

Silencing of the Caenorhabditis elegans ortholog of PSA caused defects in embryogenesis and reproduction (Brooks et al, 2003). The homozygous PSA knockout mice show dwarfism and impairment of reproductive functions in both the sexes (Osada et al, 2001a,b). Interestingly, the PSAdeficient mice also show altered locomotor activity, increased anxiety and impaired response to pain (Osada et al, 1999). Perhaps these behavioral and neurological abnormalities are related to the failure to metabolize polyQ peptides and the abnormalities seen in mice overexpressing polyQ proteins. The present findings suggest that a lack of PSA leads to a greater susceptibility to polyQ diseases as PSA appears to be critical in the clearance of polyQ sequences derived from even normal polyQ proteins, which when overproduced can a be toxic.

\section{Degradation of even normal-length polyQ peptides is unusually slow}

An important observation was that the digestion of all $\mathrm{Q}$ peptides by the cellular extracts is inherently quite inefficient. For example, the rate of digestion of $\mathrm{Q}_{20} \mathrm{RRGRR}$ is 15-fold lower than the digestion of a non-repeat 25 -residue peptide library. A typical protein is degraded by proteasomes to 3-24residue peptides (Kisselev et al, 1999). The smaller products are then digested by a set of aminopeptidases and the longer ones ( $>8$ residues) are cleaved by endopeptidases to peptides six residues or smaller, which are then hydrolyzed to amino acids by this set of aminopeptidases (Saric et al, 2004). Our results show that the degradation pathway for even the wild-type polyQ proteins is quite different (and probably proceeds more slowly). First, the proteasomes release the undigested polyQ sequences, which subsequently are hydrolyzed mainly by a single aminopeptidase (Figure 8). Although PSA is capable of digesting polyQ peptides as long as 30 residues (and maybe longer), exopeptidases are a much slower degradative mechanism than endoproteolytic cleavages followed by multiple exopeptidases. In addition, normal as well as expanded polyQ peptides are prone to oligomerization and aggregation, which may render them resistant to PSA and contribute to their accumulation. Thus, the slow clearance of polyQ peptides by PSA, especially extended ones, could be a critical factor in the development of polyQ disorders.

\section{Degradation of expanded polyQ proteins and protection against polyQ diseases}

The majority of peptide products released by proteasomes are smaller than eight residues and nearly all are shorter than 25 residues (Kisselev et al, 1999), presumably because of the narrow channel for product exit (Kohler et al, 2001). HDs and other polyQ diseases are associated with polyQ extensions longer than 35 residues (Zoghbi and Orr, 2000). As such sequences are not degraded by proteasomes, we proposed that these peptides when extended beyond 35 residues diffuse out of the proteasome only very slowly compared to typical peptide sequences (Venkatraman et al, 2004). Occasional failure of such extended polyQ peptides to exit the proteasomes would be expected to block proteasome function, as was observed in cells and animal models of polyQ disease.
Such a pathogenic mechanism could contribute to the length dependence of disease onset.

The finding that polyQ sequences are degraded by an exopeptidase mechanism indicates another negative consequence of these extended polyQ repeats that could also possibly contribute to the progression of disease and its length dependence. PSA appears exceptional compared to other cytosolic aminopeptidases, which generally prefer substrates only several residues long, in its ability to digest rapidly longer peptides, that is, it releases amino acids at similar rates from non-repeat peptides up to 42 residues. This unusual capacity of PSA to hydrolyze long peptides presumably accounts for its recently reported remarkable ability to reduce tau levels in Drosophila neurons and to protect against neurodegeneration induced by overproduction of mutant tau (Karsten et al, 2006). PSA is also unique in its ability to remove N-terminal Q's from $\mathrm{Q}_{20}$ and $\mathrm{Q}_{30}$ at rates similar to other amino acids. However, exopeptidase attack is the most inefficient enzymatic mechanism for rapid elimination of a lengthy substrate, and the longer the polyQ sequence, the longer it takes PSA to completely hydrolyze it. Furthermore, polyQ peptides of increasing Q-repeat length are prone to aggregate. In fact, such polyQ fragments are much more aggregation-prone than the original polyQ-containing protein from which they are derived. Thus, exclusive digestion by an aminopeptidase mechanism means that the potentially most toxic, aggregation-prone products of the proteasome will also be the most long-lived in the cytosol. These features could also contribute to the influence of increasing Q-repeat length on the onset of polyQ inclusions and disease symptoms. It is noteworthy that the mRNA for PSA was among those induced most highly (up to 12 -fold in a day) after overexpression of huntingtin containing $74 \mathrm{Q}$ but not with normal exon 1 (24Q) (Kita et al, 2002). This induction (which we learned about only after the present studies were submitted for publication) together with the present findings strongly implies a key role for PSA in protecting against build-up of polyQ fragments, similar to its newly discovered role in protecting neurons against tauopathies (Karsten et al, 2006).

However, in addition to PSA, cells contain other mechanisms to retard the accumulation of such poorly degraded species. Recent studies indicated that the autophagic-lysosomal pathway is also an important mechanism responsible for the clearance of inclusions formed by the expanded polyQ-containing proteins (Ravikumar et al, 2002, 2004). Presumably, the inefficient clearance of extended polyQ sequences by PSA favors the formation of cytosolic inclusions, which are then hydrolyzed in lysosomes by acid hydrolases, some of which can digest these polyQ sequences rapidly (Bhutani et al, in preparation). Although our studies have identified PSA to be the key peptidase required for the digestion of the wild-type polyQ sequences released by proteasomes under normal conditions, its importance in clearing the expanded polyQ peptides remains unclear. To what extent polyQ fragments do accumulate in PSA-deficient cells must depend on the rates of degradation of the polyQ proteins and the rate of clearance of these proteins and polyQ peptides by autophagy. These key questions should now be explored in various models of the polyQ disorders to ascertain the exact role of PSA in different cell types, to learn if the content of PSA may help determine disease susceptibility and to test whether PSA induction can retard the progression of these diseases. 


\section{Materials and methods}

\section{Peptides and enzymes}

The various polyQ peptides were a kind gift by Professor Ron Wetzel and were disaggregated, stored and used as described previously (Chen and Wetzel, 2001; Venkatraman et al, 2004). The peptide library $\mathrm{RY}\left(\mathrm{X}_{19}\right) \mathrm{NKTL}$, where ' $\mathrm{X}$ ' is an equimolar mixture of A, D, E, F, G, H, I, K, L, M, P, Q, R, S, T or V, as well as the peptides ANATKVLEVSLEY, ANATKVSKNLEKNVSKNLEY, ANATKKNSLEV SKNLE KN VSVSKNLEY and ANATKKNLEVSVSLEKNKNSLEVSKNLELEKNVSVSKNLEY were a gift from Professor Frank Momberg. The quenched $\mathrm{Q}_{9}$ peptide, $\mathrm{KKE}^{(\mathrm{EDANS})} \mathrm{Q}_{9} \mathrm{~K}^{(\mathrm{DABSYL})} \mathrm{K}$, was custom synthesized and purified to $>95 \%$ homogeneity by Genemed Synthesis Inc. Fluorogenic substrates used for assaying peptidase activities were purchased from Bachem (Basel, Switzerland). The specific peptidase inhibitors leupeptin, bestatin, pefabloc, pepstatin and E64 were purchased from Sigma, TOP inhibitor $N$-[1 $(R, S)$ carboxy-3-phenylpropyl]-Ala-Ala-Phe- $p$-aminobenzoate (Cpp-AAFpAb) was purchased from Bachem (Basel, Switzerland), butabindide was purchased from TOCRIS (UK) and PS341 was a gift from Millenium (USA). Porcine kidney LAP was purchased from Sigma and was additionally purified as described (Beninga et al, 1998). Recombinant human PSA was kindly provided by Dr Louis B Hersh, recombinant human POP was kindly provided by Dr Laszio Polger and recombinant human BH was a kind gift of Dr Leemor Joshua-Tor. Recombinant human IDE and ACE were purchased from Calbiochem.

\section{Preparation of cytosolic extracts}

To prepare cytosolic extracts (Saric et al, 2004), HeLa cells or mammalian muscle or liver tissues were resuspended in ice-cold $50 \mathrm{mM}$ sodium phosphate, $\mathrm{pH} 7.5,5 \mathrm{mM} \mathrm{MgCl}, 2 \mathrm{mM}$ ATP, $1 \mathrm{mM}$ DTT and $10 \%$ glycerol. Cell extracts were prepared by Dounce homogenization with 10 manual strokes on ice. This homogenate was spun at $10000 \mathrm{~g}$ for $15 \mathrm{~min}$ to remove the nuclear fraction and then at a higher speed of $100000 \mathrm{~g}$ to remove membranous organelles. The resulting supernatant fractions were aliquoted, snap-frozen in liquid nitrogen and stored at $-80^{\circ} \mathrm{C}$ until use. Both the 10000 and $100000 \mathrm{~g}$ supernatants were tested for cytosolic peptidases at $\mathrm{pH} \mathrm{7,} \mathrm{to} \mathrm{ensure} \mathrm{that} \mathrm{there} \mathrm{was} \mathrm{no} \mathrm{loss} \mathrm{of} \mathrm{relevant}$ peptidases by the high-speed centrifugation.

\section{Fractionation of HeLa extracts}

HeLa $(50 \mathrm{mg})$ extracts, devoid of the nuclear fraction and kindly provided by Dr Robin Reed's laboratory, were subjected to highspeed centrifugation at $65000 \mathrm{~g}$ for $6 \mathrm{~h}$ in order to completely remove the proteasome activity initially present in the extract. The resulting supernatant was fractionated by ion-exchange chromatography on a $250 \mathrm{ml}$ DE- 52 column in $50 \mathrm{mM}$ Tris- $\mathrm{HCl}$, pH 7.5, $5 \mathrm{mM}$ $\mathrm{MgCl}_{2}, 1 \mathrm{mM}$ ATP, $1 \mathrm{mM}$ DTT and $10 \%$ glycerol. Bound proteins were eluted in a $500 \mathrm{ml}$ gradient from 0 to $0.5 \mathrm{M} \mathrm{NaCl}$ and $5 \mathrm{ml}$ fractions were collected. Five-microliter aliquots of the fractions were analyzed for their ability to hydrolyze $100 \mu \mathrm{M}$ Q-amc and $10 \mu \mathrm{M}$ $\mathrm{KKE}^{(\mathrm{EDANS})} \mathrm{Q}_{9} \mathrm{~K}^{(\mathrm{DABSYL})} \mathrm{K}$. The fractions corresponding to the single, overlapping activity peak against both the substrates were pooled, concentrated and further fractionated on a Resource ${ }^{\mathrm{TM}} \mathrm{RPC}$ column. Bound proteins were eluted in a $100 \mathrm{ml}$ gradient from 0.2 to $0 \mathrm{M}$ $\mathrm{NaCl}$. Five-microliter aliquots were analyzed for their ability to hydrolyze $100 \mu \mathrm{M}$ Q-amc and $10 \mu \mathrm{M} \mathrm{KKE}{ }^{(\mathrm{EDANS})} \mathrm{Q}_{9} \mathrm{~K}^{(\mathrm{DABSYL})} \mathrm{K}$. The fractions corresponding to the active peak were pooled, concentrated, desalted and further fractionated on a CHT hydroxyapatite column. There was no activity in the flow-through fractions. Upon batch-elution in steps of $0.1 \mathrm{M}$ phosphate, only the $0.2 \mathrm{M}$ phosphate peak showed activity against both the substrates. The $0.2 \mathrm{M}$ fractions were desalted, concentrated and analyzed by a native PAGE activity overlay using the fluorogenic substrate $\mathrm{Q}$-amc and the quenched $\mathrm{Q}_{9}$. Crude extract and the concentrated Q-active pool were run on a native PAGE and the gel was incubated in $10 \mathrm{ml}$ of $100 \mu \mathrm{M}$ Q-amc for $30 \mathrm{~min}$. Q-amc hydrolysis by the active enzyme generated a fluorescent band that was visualized using a gel document system (Bio-Rad). The active fluorescent band was excised and run on an SDS-PAGE. Two bands corresponding to 98 and $62 \mathrm{kDa}$ were visible. These bands were excised, eluted and identified using LC-MS.

\section{Peptide product analysis}

$\mathrm{N}$ termini of new peptides, generated by enzyme digestion, interact with fluorescamine (Udenfriend et al, 1972). After the reaction, $5 \mu \mathrm{l}$ of each sample was first mixed with $50 \mu \mathrm{l}$ of $0.2 \mathrm{M}$ sodium phosphate, $\mathrm{pH} 7$, and then mixed and rotated with $25 \mu \mathrm{l}$ of fluorescamine solution in acetone $(0.3 \mathrm{mg} / \mathrm{ml})$ for $3 \mathrm{~min}$. Reaction was arrested by diluting the mixture with $200 \mu$ lof ice-cold water. A $200 \mu \mathrm{l}$ measure of each sample was then transferred to a 96-well plate and measured with the FLUOstar Galaxy plate reader (BMG Labtechnologies Inc.) at an excitation wavelength of $380 \mathrm{~nm}$ and an emission wavelength of $480 \mathrm{~nm}$. An equimolar mixture of peptides of known concentration (EAA- $\mathrm{NH}_{2}$, AEAA- $\mathrm{NH}_{2}$, AAEAAG- $\mathrm{NH}_{2}$, AAVVAAG and TTQRTRALV) was used as the standard to calculate the amount of new peptide products generated. Alternatively, aliquots of the reaction mixtures were directly analyzed by matrixassisted laser desorption/ionization-time of flight mass spectrometry (MALDI-TOF MS; Applied Biosytems Voyager 4036 at the Danafarber Core Facility), using the linear mode of analysis to increase the sensitivity of detection, as described (Venkatraman et al, 2004).

\section{Purification of TPPII}

TPPII was purified from young rabbit muscle, using high concentrations of DTT and ammonium sulfate for stabilizing its structure as reported for the Drosophila homolog (Rockel et al, 2002). After the muscles were minced to small pieces, they were homogenized in a buffer containing $50 \mathrm{mM}$ sodium phosphate, $\mathrm{pH}$ 7.5, $0.25 \mathrm{M}$ sucrose, $5 \mathrm{mM}$ DTT, $5 \mathrm{mM} \mathrm{MgCl} 2,2 \mathrm{mM}$ ATP and $10 \%$ glycerol. The homogenate was centrifuged for $15 \mathrm{~min}$ at $10000 \mathrm{~g}$ to remove cell debris and then was centrifuged for $1 \mathrm{~h}$ at $100000 \mathrm{~g}$ to remove membranous fractions. The supernatants were loaded onto a DE-52 column (Whatman) and, after washing, were eluted with a linear gradient of $0-400 \mathrm{mM}$ ammonium sulfate. TPPII protein peak was followed by butabindide-sensitive activity against AAF-amc. Active fractions were collected, loaded on a Resource Q column after diluting the ammonium sulfate concentration to $10 \mathrm{mM}$ and eluted with a linear gradient of $0-300 \mathrm{mM}$ ammonium sulfate. Fractions from the Resource Q column containing TPPII (i.e. AAFamc activity that was inhibited by $4 \mathrm{nM}$ butabindide) were concentrated to $1 \mathrm{ml}$ and loaded on a 38-ml glycerol gradient (23$37 \%$ glycerol in $25 \mathrm{mM}$ HEPES, pH 7.5, $5 \mathrm{mM}$ DTT, $0.5 \mathrm{mM}$ ATP, $5 \mathrm{mM} \mathrm{MgCl}_{2}$ ) in a swinging bucket rotor SW 28 (Beckman). After centrifugation for $22 \mathrm{~h}$ at $100000 \mathrm{~g}$, the gradient was fractionated and the fractions active against AAF-amc were pooled and concentrated. The resulting preparations were free of proteasomes as they showed no activity against the proteasomal substrate SucLLVY-amc, and of aminopeptidases as the activity against AAF-amc was not affected by the aminopeptidase inhibitor bestatin.

\section{siRNA experiments}

RNA oligonucleotides mTOP1 (directed to the base positions 673-691 of mouse TOP (GenBank accession no. XM_122062)) used as a control siRNA, TPPII (directed to base positions 1017-1035 of human TPPII (GenBank accession no. M73047) and PSA (directed to base positions $2405-2423$ of the human PSA (GenBank accession no. NM_006310)) were purchased from Dharmacon (Lafeyette, CO) and annealed as described (Elbashir et al, 2001). HeLa cells were transfected with the siRNA as previously described (York et al, $2002,2003)$. mRNA was extracted from cells using an RNeasy kit (Qiagen) and cDNA was prepared using SuperScript II (Invitrogen). RT-PCR or real-time PCR was performed using primers directed against TPPII (GGTGGGCAAGTCTCAGTGAT and CATCAAAGCGG TTGATTCCT), ERAP1 (GGGAGCTGGAGAGAGGCTAT and CTTGCTT TGAAGGCAGGTTC), PSA (CTCAACTCTCTTGTCCCAC and GGAGTG CATCGAGATGACC), TOP (ACTTCCCCCTCCTGAAGAAA and CCTT GAGGATAGCGCAGTTC) and $\beta$-actin (CGAGGCCCAGAGCAAGAGAG and CGGTTGGCCTTAGGGTTCAG). Cytosolic cell extracts were prepared and the activities against fluorogenic substrates were measured as described above.

\section{Supplementary data}

Supplementary data are available at The EMBO Journal Online (http://www.embojournal.org).

\section{Acknowledgements}

These findings were made possible by research grants from the High Q Foundation and the Fund for Innovation from Elan 
Pharmaceuticals. During this work, Dr Goldberg was a senior fellow of the Ellison Foundation. We thank Dr Ian York and Dr CF Towne from Professor Ken Rock's laboratory for kindly providing us the knowledge and reagents for the TppII and PSA siRNA experiments We are grateful to Mary Dethavong for expert assistance in the preparation of this manuscript.

\section{References}

Bence NF, Sampat RM, Kopito RR (2001) Impairment of the ubiquitin-proteasome system by protein aggregation. Science 292: $1552-1555$

Beninga J, Rock KL, Goldberg AL (1998) Interferon-gamma can stimulate post-proteasomal trimming of the $\mathrm{N}$ terminus of an antigenic peptide by inducing leucine aminopeptidase. J Biol Chem 273: $18734-18742$

Botbol V, Scornik OA (1983) Peptide intermediates in the degradation of cellular proteins. Bestatin permits their accumulation in mouse liver in vivo. J Biol Chem 258: 1942-1949

Brooks DR, Hooper NM, Isaac RE (2003) The Caenorhabditis elegans orthologue of mammalian puromycin-sensitive aminopeptidase has roles in embryogenesis and reproduction. $J$ Biol Chem 278: 42795-42801

Chai Y, Wu L, Griffin JD, Paulson HL (2001) The role of protein composition in specifying nuclear inclusion formation in polyglutamine disease. J Biol Chem 276: 44889-44897

Chang SC, Momburg F, Bhutani N, Goldberg AL (2005) The ER aminopeptidase, ERAP1, trims precursors to lengths of MHC class I peptides by a 'molecular ruler' mechanism. Proc Natl Acad Sci USA 102: $17107-17112$

Chen S, Wetzel R (2001) Solubilization and disaggregation of polyglutamine peptides. Protein Sci 10: 887-891

Constam DB, Tobler AR, Rensing-Ehl A, Kemler I, Hersh LB, Fontana A (1995) Puromycin-sensitive aminopeptidase. Sequence analysis, expression, and functional characterization. J Biol Chem 270: 26931-26939

Davies SW, Turmaine M, Cozens BA, DiFiglia M, Sharp AH, Ross CA, Scherzinger E, Wanker EE, Mangiarini L, Bates GP (1997) Formation of neuronal intranuclear inclusions underlies the neurological dysfunction in mice transgenic for the HD mutation. Cell 90: $537-548$

Dyer RB, McMurray CT (2001) Mutant protein in Huntington disease is resistant to proteolysis in affected brain. Nat Genet 29: $270-278$

Elbashir SM, Harborth J, Lendeckel W, Yalcin A, Weber K, Tuschl T (2001) Duplexes of 21-nucleotide RNAs mediate RNA interference in cultured mammalian cells. Nature 411: 494-498

Farris W, Mansourian S, Chang Y, Lindsley L, Eckman EA, Frosch MP, Eckman CB, Tanzi RE, Selkoe DJ, Guenette S (2003) Insulindegrading enzyme regulates the levels of insulin, amyloid betaprotein, and the beta-amyloid precursor protein intracellular domain in vivo. Proc Natl Acad Sci USA 100: 4162-4167

Fulop V, Bocskei Z, Polgar L (1998) Prolyl oligopeptidase: an unusual beta-propeller domain regulates proteolysis. Cell 94: $161-170$

Geier E, Pfeifer G, Wilm M, Lucchiari-Hartz M, Baumeister W, Eichmann K, Niedermann G (1999) A giant protease with potential to substitute for some functions of the proteasome. Science 283: $978-981$

Goldberg AL (2003) Protein degradation and protection against misfolded or damaged proteins. Nature 426: 895-899

Hara T, Nakamura K, Matsui M, Yamamoto A, Nakahara Y, SuzukiMigishima R, Yokoyama M, Mishima K, Saito I, Okano H, Mizushima N (2006) Suppression of basal autophagy in neural cells causes neurodegenerative disease in mice. Nature 441: 885-889

Hersh LB (1981) Inhibition of aminopeptidase and acetylcholinesterase by puromycin and puromycin analogs. J Neurochem 36: 1594-1596

Hersh LB, McKelvy JF (1981) An aminopeptidase from bovine brain which catalyzes the hydrolysis of enkephalin. J Neurochem 36: 171-178

Hersh LB, Smith TE, McKelvy JF (1980) Cleavage of endorphins to des-Tyr endorphins by homogeneous bovine brain aminopeptidase. Nature 286: 160-162

Holmberg CI, Staniszewski KE, Mensah KN, Matouschek A, Morimoto RI (2004) Inefficient degradation of truncated polyglutamine proteins by the proteasome. EMBO J 23: 4307-4318
Hu J, Igarashi A, Kamata M, Nakagawa H (2001) Angiotensinconverting enzyme degrades Alzheimer amyloid beta-peptide (A beta); retards A beta aggregation, deposition, fibril formation; and inhibits cytotoxicity. J Biol Chem 276: 47863-47868

Jana NR, Zemskov EA, Wang G, Nukina N (2001) Altered proteasomal function due to the expression of polyglutamine-expanded truncated N-terminal huntingtin induces apoptosis by caspase activation through mitochondrial cytochrome $c$ release. Hum Mol Genet 10: 1049-1059

Johnson GD, Hersh LB (1990) Studies on the subsite specificity of the rat brain puromycin-sensitive aminopeptidase. Arch Biochem Biophys 276: 305-309

Karsten SL, Sang TK, Gehman LT, Chatteriee S, Liu J, Lawless GM, Sengupta S, Berry RW, Pomakian J, Oh HS, Schulz C, Hui KS, Wiedau-Pazos M, Vinters HV, Binder LI, Geschwind DH, Jackson GR (2006) A genomic screen for modifiers of tauopathy identifies puromycin-sensitive aminopeptidase as an inhibitor of tauinduced neurodegeneration. Neuron 51: 549-560

Kazantsev A, Preisinger E, Dranovsky A, Goldgaber D, Housman D (1999) Insoluble detergent-resistant aggregates form between pathological and nonpathological lengths of polyglutamine in mammalian cells. Proc Natl Acad Sci USA 96: 11404-11409

Kisselev AF, Akopian TN, Woo KM, Goldberg AL (1999) The sizes of peptides generated from protein by mammalian 26 and $20 \mathrm{~S}$ proteasomes. Implications for understanding the degradative mechanism and antigen presentation. $J$ Biol Chem 274: 3363-3371

Kita H, Carmichael J, Swartz J, Muro S, Wyttenbach A, Matsubara K, Rubinsztein DC, Kato K (2002) Modulation of polyglutamineinduced cell death by genes identified by expression profiling. Hum Mol Genet 11: 2279-2287

Kohler A, Cascio P, Leggett DS, Woo KM, Goldberg AL, Finley D (2001) The axial channel of the proteasome core particle is gated by the Rpt2 ATPase and controls both substrate entry and product release. Mol Cell 7: 1143-1152

Komatsu M, Waguri S, Chiba T, Murata S, Iwata J, Tanida I, Ueno T, Koike M, Uchiyama Y, Kominami E, Tanaka K (2006) Loss of autophagy in the central nervous system causes neurodegeneration in mice. Nature 441: $880-884$

Oliveira V, Campos M, Melo RL, Ferro ES, Camargo AC, Juliano MA, Juliano L (2001) Substrate specificity characterization of recombinant metallo oligo-peptidases thimet oligopeptidase and neurolysin. Biochemistry 40: 4417-4425

Osada T, Ikegami S, Takiguchi-Hayashi K, Yamazaki Y, Katoh-Fukui Y, Higashinakagawa T, Sakaki Y, Takeuchi T (1999) Increased anxiety and impaired pain response in puromycin-sensitive aminopeptidase gene-deficient mice obtained by a mouse gene-trap method. J Neurosci 19: 6068-6078

Osada T, Watanabe G, Kondo S, Toyoda M, Sakaki Y, Takeuchi T (2001a) Male reproductive defects caused by puromycinsensitive aminopeptidase deficiency in mice. Mol Endocrinol 15: 960-971

Osada T, Watanabe G, Sakaki Y, Takeuchi T (2001b) Puromycinsensitive aminopeptidase is essential for the maternal recognition of pregnancy in mice. Mol Endocrinol 15: 882-893

Ravikumar B, Duden R, Rubinsztein DC (2002) Aggregate-prone proteins with polyglutamine and polyalanine expansions are degraded by autophagy. Hum Mol Genet 11: 1107-1117

Ravikumar B, Vacher C, Berger Z, Davies JE, Luo S, Oroz LG, Scaravilli F, Easton DF, Duden R, O'Kane CJ, Rubinsztein DC (2004) Inhibition of mTOR induces autophagy and reduces toxicity of polyglutamine expansions in fly and mouse models of Huntington disease. Nat Genet 36: 585-595

Reits E, Griekspoor A, Neijssen J, Groothuis T, Jalink K, van Veelen P, Janssen H, Calafat J, Drijfhout JW, Neefjes J (2003) Peptide diffusion, protection, and degradation in nuclear and cytoplasmic compartments before antigen presentation by MHC class I. Immunity 18: 97-108 
Reits E, Neijssen J, Herberts C, Benckhuijsen W, Janssen L, Drijfhout JW, Neefjes J (2004) A major role for TPPII in trimming proteasomal degradation products for MHC class I antigen presentation. Immunity 20: 495-506

Rock KL, York IA, Goldberg AL (2004) Post-proteasomal antigen processing for major histocompatibility complex class I presentation. Nat Immunol 5: 670-677

Rockel B, Peters J, Kuhlmorgen B, Glaeser RM, Baumeister W (2002) A giant protease with a twist: the TPP II complex from Drosophila studied by electron microscopy. EMBO J 21: 5979-5984

Rockel B, Peters J, Muller SA, Seyit G, Ringler P, Hegerl R, Glaeser RM, Baumeister W (2005) Molecular architecture and assembly mechanism of Drosophila tripeptidyl peptidase II. Proc Natl Acad Sci USA 102: 10135-10140

Rose C, Vargas F, Facchinetti P, Bourgeat P, Bambal RB, Bishop PB, Chan SM, Moore AN, Ganellin CR, Schwartz JC (1996) Characterization and inhibition of a cholecystokinin-inactivating serine peptidase. Nature 380: 403-409

Saric T, Beninga J, Graef CI, Akopian TN, Rock KL, Goldberg AL (2001) Major histocompatibility complex class I-presented antigenic peptides are degraded in cytosolic extracts primarily by thimet oligopeptidase. J Biol Chem 276: 36474-36481

Saric T, Graef CI, Goldberg AL (2004) Pathway for degradation of peptides generated by proteasomes: a key role for thimet oligopeptidase and other metallopeptidases. J Biol Chem 279: 46723-46732

Seifert U, Maranon C, Shmueli A, Desoutter JF, Wesoloski L, Janek K, Henklein P, Diescher S, Andrieu M, de la Salle H, Weinschenk T, Schild H, Laderach D, Galy A, Haas G, Kloetzel PM, Reiss Y, Hosmalin A (2003) An essential role for tripeptidyl peptidase in the generation of an MHC class I epitope. Nat Immunol 4: 375-379

Steffan JS, Kazantsev A, Spasic-Boskovic O, Greenwald M, Zhu YZ, Gohler H, Wanker EE, Bates GP, Housman DE, Thompson LM (2000) The Huntington's disease protein interacts with p53 and CREB-binding protein and represses transcription. Proc Natl Acad Sci USA 97: 6763-6768

Stoltze L, Schirle M, Schwarz G, Schroter C, Thompson MW, Hersh LB, Kalbacher H, Stevanovic S, Rammensee HG, Schild H (2000) Two new proteases in the MHC class I processing pathway. Nat Immunol 1: 413-418
Thompson MW, Hersh LB (2003) Analysis of conserved residues of the human puromycin-sensitive aminopeptidase. Peptides 24: 1359-1365

Thompson MW, Govindaswami M, Hersh LB (2003) Mutation of active site residues of the puromycin-sensitive aminopeptidase: conversion of the enzyme into a catalytically inactive binding protein. Arch Biochem Biophys 413: 236-242

Udenfriend S, Stein S, Bohlen P, Dairman W, Leimgruber W, Weigele M (1972) Fluorescamine: a reagent for assay of amino acids, peptides, proteins, and primary amines in the picomole range. Science 178: 871-872

Umezawa H, Aoyagi T, Suda H, Hamada M, Takeuchi T (1976) Bestatin, an inhibitor of aminopeptidase B, produced by actinomycetes. J Antibiot (Tokyo) 29: 97-99

Venkatraman P, Wetzel R, Tanaka M, Nukina N, Goldberg AL (2004) Eukaryotic proteasomes cannot digest polyglutamine sequences and release them during degradation of polyglutamine-containing proteins. Mol Cell 14: 95-104

Verhoef LG, Lindsten K, Masucci MG, Dantuma NP (2002) Aggregate formation inhibits proteasomal degradation of polyglutamine proteins. Hum Mol Genet 11: 2689-2700

Waelter S, Boeddrich A, Lurz R, Scherzinger E, Lueder G, Lehrach H, Wanker EE (2001) Accumulation of mutant huntingtin fragments in aggresome-like inclusion bodies as a result of insufficient protein degradation. Mol Biol Cell 12: 1393-1407

York IA, Bhutani N, Zendzian S, Goldberg AL, Rock KL (2006) Tripeptidyl peptidase II is the major peptidase needed to trim long antigenic precursors, but is not required for most MHC class I antigen presentation. J Immunol 177: 1434-1443

York IA, Chang SC, Saric T, Keys JA, Favreau JM, Goldberg AL, Rock KL (2002) The ER aminopeptidase ERAP1 enhances or limits antigen presentation by trimming epitopes to 8-9 residues. Nat Immunol 3: 1177-1184

York IA, Mo AX, Lemerise K, Zeng W, Shen Y, Abraham CR, Saric T, Goldberg AL, Rock KL (2003) The cytosolic endopeptidase, thimet oligopeptidase, destroys antigenic peptides and limits the extent of MHC class I antigen presentation. Immunity 18: 429-440

Zoghbi HY, Orr HT (2000) Glutamine repeats and neurodegeneration. Annu Rev Neurosci 23: 217-247 